\title{
Islamic Youth Participation in The Emergence of Local Ritual: Encountering The Spirit of Islam in The Local Tradition
}

\section{Taufiqurrohim}

Center for Religious and Cross Cultural Studies, UIN Sunan Kalijaga

Email: taufiqurrohim@yahoo.co.id

\begin{tabular}{|c|c|}
\hline Keywords: & Abstract: \\
\hline $\begin{array}{l}\text { Muslim Youth, Local } \\
\text { Festival, Multi- } \\
\text { culture, Spectacle } \\
\text { Attraction }\end{array}$ & $\begin{array}{l}\text { How Muslim youth encountering local festival is fascinating discourse in the age } \\
\text { where the spirit of Islamic revivalism is going on. By this, Dieng Culture Festival is } \\
\text { known as one of the popular annual ritual which performs the traditional cultural } \\
\text { attraction in Central Java, especially in Banjarnegara and Wonosobo which is heavily } \\
\text { rooted on Javanese Hindu tradition. The different perspective of the awareness in } \\
\text { considering the Importance of the ritual comes from the diverse community and } \\
\text { society to acknowledge this kind of the ritual. So, this paper tries to examine the } \\
\text { participation of the youth in enduring the annual festival as one of the events which } \\
\text { not only give the advantage for the sustainability of the ritual itself, but also influence } \\
\text { to the society around the place economically, socially and spiritually. Through youth } \\
\text { participation, this research would try to reveal how youth is significant resource to } \\
\text { build multi-cultural community. Using the theory of the "spectacle attraction", the } \\
\text { writer tries to trace how useful the ritual effecting Dieng as one of the wellknown } \\
\text { place of the tourism and spiritually affecting to the way of religious life to see the } \\
\text { ritual through the direct observation to the place, interview the practitioner of the } \\
\text { ritual and the documentation review as the supporting data of the research. Here, I } \\
\text { argue that encountering Islam and local tradition has shaped Muslim youth identity in } \\
\text { understanding local community and multi-cultural society. }\end{array}$ \\
\hline Kata kunci: & Abstrak: \\
\hline $\begin{array}{l}\text { Pemuda Muslim, } \\
\text { Festival Lokal, Multi- } \\
\text { budaya, Atraksi } \\
\text { Pertunjukan }\end{array}$ & $\begin{array}{l}\text { Bagaimana kaum muda Muslim menghadapi festival lokal adalah wacana yang } \\
\text { menarik di zaman di mana semangat revivalisme Islam sedang terjadi. Dengan ini, } \\
\text { Festival Budaya Dieng dikenal sebagai salah satu ritual tahunan populer yang } \\
\text { melakukan atraksi budaya tradisional di Jawa Tengah, terutama di Banjarnegara dan } \\
\text { Wonosobo yang berakar kuat pada tradisi Hindu Jawa. Perspektif yang berbeda dari } \\
\text { kesadaran dalam mempertimbangkan Pentingnya ritual berasal dari beragam } \\
\text { komunitas dan masyarakat untuk mengakui ritual semacam ini. Jadi, makalah ini } \\
\text { mencoba untuk menguji partisipasi pemuda dalam menjalani festival tahunan sebagai } \\
\text { salah satu acara yang tidak hanya memberikan keuntungan bagi keberlanjutan ritual } \\
\text { itu sendiri, tetapi juga mempengaruhi masyarakat di sekitar tempat itu secara } \\
\text { ekonomi, sosial dan spiritual. . Melalui partisipasi pemuda, penelitian ini akan } \\
\text { mencoba mengungkap bagaimana pemuda adalah sumber daya yang signifikan untuk } \\
\text { membangun komunitas multi-budaya. Dengan menggunakan teori "atraksi tontonan", } \\
\text { penulis mencoba menelusuri seberapa berguna ritual yang memengaruhi Dieng } \\
\text { sebagai salah satu tempat pariwisata yang terkenal dan yang secara spiritual } \\
\text { memengaruhi cara hidup keagamaan untuk melihat ritual melalui pengamatan } \\
\text { langsung ke tempat itu. , mewawancarai praktisi ritual dan tinjauan dokumentasi } \\
\text { sebagai data pendukung penelitian. Di sini, saya berpendapat bahwa menghadapi } \\
\text { Islam dan tradisi lokal telah membentuk identitas pemuda Muslim dalam memahami } \\
\text { komunitas lokal dan masyarakat multi-budaya. }\end{array}$ \\
\hline
\end{tabular}




\section{Introduction}

The ritual repertoire is very diffuse which some people still question about the role with the religious belief. For some extends, ritual has the purpose as the therapeutic context especially in emotion and spiritual recovery unexceptionally in disaster order. Here, the religious belief plays a basic role in response of the existence of the rites due to its value is useless and contradicted with their belief. Again, the critics also come from the perspective 'narcissism' which assume ritual make people went wrong and lack of the disaster management (Post 2003: 6).

Here, the writer tries to examine the position of the argument with the case of ruwatan rambut gembel as the basic point in order to find what is the role of the ritual connecting with the practitioner and inhabitant belief with this kind of festival. I argue that the religious sect and belief influenced to ritual repertoire in assuming its role for the society. Indeed, the significance of the ritual can reduce the disaster remembrance as the traumatic recovery and effected to the pattern of the society to see the ritual positively. Moreover, the attendance of the spirit of Islam among Youth Muslim gives a bridge in finding a conducive situation and mutual understanding in the multiculturalism society due to the its diversity of the culture.

Therefore, this paper firstly tries to explain the myth of the ritual and its belief among the practitioner of the Dieng Culture Festival to find the emergences. Next, tracing the response of the ritual is the influential explanation that can be considered, regarding the situation of Dieng people which has multiculturalism society. The involvement of the youth is the last and the main discussion of this paper which encourage the motive of the youth to conserve the annual culture due to its influence to the society not only creating the public diversity consideration but also concerning to the development of the tourism affecting to economic, spiritual and other social matters.

\section{Research Method}

In this research, in the context of collecting data, the writer uses literature studies where in collecting data related to local culture, such as the Dieng festival. Where the Dieng Culture Festival is known as one of the popular annual rituals that performs traditional cultural attractions in Central Java, especially in Banjarnegara and Wonosobo which are firmly rooted in Javanese Hindu traditions. Different perspectives of awareness in considering the importance of rituals come from a variety of communities and communities to recognize this kind of ritual. So, this paper tries to examine the participation of youth in undergoing an annual festival as one of the events that not only benefits the sustainability of the ritual itself, but also affects the surrounding community economically, socially and spiritually.

Through youth participation, this research will try to uncover how youth are significant resources for building multi-cultural communities. By using the theory of "spectacle attraction", the author tries to explore how useful rituals that affect Dieng as one of the famous tourism sites and which spiritually influence the way of religious life to see the ritual through direct observation to that place., interviewing ritual practitioners and reviewing documentation as supporting research data. Here, I am of the opinion that facing Islam and local traditions has shaped the identity of Muslim youth in understanding local communities and multi-cultural societies by using some literature sourced from research journals. Data analysis in the writing of this paper is presented in the form of data presentation can be done in the form of a brief description, charts, relationships between categories and the like, but the most often used is a narrative text Sugiyono (2005) 


\section{Results and Discussions}

\section{a. The Myth of Rambut Gembel in Dieng Culture Festival}

The Kids with rambut gembel1 at Dieng Plateau, is a such phenomenon are interesting to be examined. The tangled hair grows in children, not because of genetic factors, or because they never wash your hair. This phenomenon cannot be explained biologically. Symptoms of hair grows tangled make his parents very concerned. This is what makes the parents Child with rambut gembel, trying to accept the fate that their child haired is tangled. Children's tangled hair favored by his family, because the tangled hair draws our attention to see their lives further.

Therefore, at the time of his front teeth children are dated, tangled hair must be cut with a ritual. Time ritual child's request must be obeyed, and should be appropriate, there should be no less. Nyi Roro kidul is often associated with child tangled hair. but it is not just her that is associated with rambut gembel. There is also Kiai Kolodete, Dewi Laras Jinde Nini, Nini Legs and Robyong. Some of these figures correlate with the presence of the phenomenon of child tangled hair in the Dieng Plateau. The Javanese beliefs seen in how they are treated special in their family, and when the ritual cutting tangled hair. Children's tangled hair is believed to be a surrogate of natural supernatural, which must be treated well, all requests must be obeyed.

The aim is to come to terms with the natural inhabitants of the supernatural, which believed to be the caretaker of children tangled hair. This is also a reception destiny that cannot be avoided, because the child's tangled hair cannot be held or denied by anyone. In a ritual, tangled haircuts seen an attempt to adjust to the supernatural realm, where there are offerings that no longer tangled hair back with her children. The phenomenon of children's hair tangled can be explained by the theory of connection between myth and ritual.

Esposito (2006) stated the myth is a symbolic story of the human history which related to the ultimately govern the destiny and has particular power expected for them. The ritual explained as the action connecting to the sacralized story which has descended from one generations next so the festival held is basic periodical result of the myth and ritual embedded by the sacred of the human destiny (Esposito 2006: 8). But the conflict here, when The existence of two forms Different approach of the religious belief, which must always exist and cannot be united, distinguishing the sacred and the profane. This is to show that the child This tangled hair is sacralized to the people of the Dieng Plateau. Currently, children tangled hair into a main attraction for Dieng Plateau travelers. 1 Gembel means dirty, tousled, or unlucky 2 The mystical Queen of the South Coast of Java 3 Interviewed with Hartono (48) on 29 July 2016.

When rituals are tangled haircut festival implemented, many people participated in this procession and profitable for tourist attraction. This is where looks faded hair sanctity of child beggars. Therefore, something sacralized is determined by the community, as well as when the value of something sacred fade and become profane, and the society is the one who make this decision. This paper tries to answer what is the meaning ruwatan ritual connecting with the disaster discourses and religious belief?

\section{b. The Meaning of The Ruwatan and Disaster Interpretation}

Ruwatan originally from the word Javanese Language ruwat with the additional -an in the last of the word. Ruwat means cleansing from the wholly about the bad luck and the dirty thing (spiritually) inside the people, community or such of thing as like land, village, animal or trees. Ruwatan is a usual Javanese practice to purify the bad thing inside which has particular requirement that should be obey as like taking bath with the seven flower, gamelan music, wayang and the other ritual. As like the kids who get rambut gembel, they should purify with such of the ceremony because 
of that gift but sometimes tangled hair known as the disaster for them. To connecting ritual with the disaster discourses, I will start the next discussion with the question how categorization of disaster come from personal to the group of responsibility of the disaster?

While, the definition of the disaster still debatable among scholars coming from the scientific or social view in defining disaster. as Kemkens (2013) cited from Oliver Smith said that there was no consensus to disaster definitions which set of the physical impact or social constructed perception. The theory of Robert Stallings (2005) on "disaster, crisis, collective stress and Mass Deprivation" is the basic point I take here which collective stress as the main point. The "mandate" and "social system" from the Barton's definitions of disaster can be typologies at the disaster repertoire (2005: 243).

Rambut gembel can be seen as a mandate for every to help the people who the disaster. As the explanation above, the tangled hair is the personal disaster that make much people have a sympathy because they can purify the bad luck by particular ritual which spends a lot of money. The existence of the cutting of rambut gembel Festival can be said as the social system which in this ceremony.

Furthermore, in social field, I will agree with Kreps's exploration (1998: 26) in disaster as systematic event and social catalyst For some time now, sociologists have interpreted disasters as special types of societal phenomena, in part because they are dramatic historical happenings (events), and also because they compel collective reactions (social catalysts). By recognizing these key conceptual features of disasters, we are able to see how and why they can be distinguished from environmental hazards of various types, and an even broader range of societal concerns.

Interestingly, Kreps criticizes about that concept, because based on him, the disaster scope in natural disaster, physical harm and social disruption rather than categorized social issues on disaster as collective reaction. But here I will use the "traditionalist approach" had been used by Kreps because it caged on the reciprocal exploration, the future understanding of the disaster may spread around the socialists which interest in this kind of case. So the exploration of the disaster phenomenon, I think, not merely about the scientific explanation but it should involve social issues. It causes the social catalyst during disaster as like politic, humanistic and also psychological approach. In the other hand, examining the disaster in social issues is so very risk.

Hence, its divisions reflect to the framing and locating the inhabitant religious interpretation to the meanings attached to catastrophic events by local populations (Kearnes 2012: 50). The very problematic approach around the disaster issues is clash of the religious belief with the role of the ritual. The assumption of the does not make sense and ritual is unappropriated with the religious teaching always rise in the surface. So the next, the will discuss about those explorations which connected with study case of Dieng.

\section{c. The Connection Religious Belief and Ritual}

The functions and dysfunction of the religious belief is influence to the people who believe in of the disasters including the effect of the ritual to the disaster. Kemkens provides three considerations that should be mentioned when We talk about disaster. the first one is the religious belief is not come from suddenly response but it was from such of the process influencing the people who face the disaster. Furthermore, the religious belief and practice is not static but dynamic and the last is no conclusion can be drawn for the people who face disaster giving more benefit because of its religion (Kemkens 2013: 60).

The similar religious background will interpret with the same way and will take it as the simultaneously a tendency of the mutual interpretation due to the local culture (2013: 70). So automatically, it cannot be avoided that with the different of the religious background also has various interpretation to the ritual. The interview with Mbah Muji (68) one of the sesepuh desa4 describe that there are some Islamic sects which spread in the villages in Dieng Volcano Range, this kind of situation effected to the response with some ritual which had been existed in Dieng Plateau. 
Most of the People in Dieng followed Nahdhatul Ulama' (NU) as their religious sect, or as the traditionalist one who can embrace such of the cultural ritual as like Ruwatan rambut gembel. But for the first, the Muhammadiyah one which at the first of the ceremony, they did not join in this kind of the ritual. By the time, they join the ceremony without questioning the importance and the role of the ritual. The difference approach had been done by Salafiyah movement which try to ignore and did not acknowledge the ritual in their religious belief. Mbah Muji added that the existence of Salafiyah is only in two village, Pekasiran and Sumberrejo, one of the village in Batur Banjarnegara, which started rom ten years ago.

The attendance of the Salafiyah is supported with headman who supported its teaching spreading. And by the time, the local cultural and religious ritual as like sedekah bumi, tahlilan and maulidan is lost from its village. Salafiyah is known as the resurgence movement that tries to back the Islamic tradition and culture which happened in prophet Mohammad era. In his book 'The Making of Sufism: Islamic Reform in Twentieth Century", Henry Lauziere identified that Salafism as the reformist one which include the modernist perspective in twentieth century as like Al Afghani and Abduh talk as salafy through its writing.

The next is purist islam means that Salafist as the most authentic and the purist one, unsullied by any innovation (bida), deviation (inirf), or accretion (iyda) and uncontaminated by exogenous influences. It is the pure Islam to which the pious ancestors of the first three generations conformed and the last The old people which respect and honor by most of the people in the village and often ask to lead the ceremony and ritual. Interviewed on 30 July 2016 is "originalist" approach to the theologies means that they did not recognize about first fitna, or civil war, which split the Muslim community in the mid-seventh century. They find all of them including the Ashari and Maturidi doctrines followed by millions of Muslims today - to be misguided, heretical, or oensive to God in one way or another (Henry 2016: 6-7).

It can be seen why most of the Salafism adherent refuse the religious and cultural ritual that had been existed before them. The assumption to purify as the "purist one" become a basic point for them. The resurgence to back and originalize the pure Islam that had been contaminated by perspective Ashari and Maturidi is the different issues for them. Interestingly Dieng Volcano Range, specifically in Pekasiran and Sumberrejo has a long history with the big disaster happened in that place. The first one is the eruption of the poisonous Sinila Crater who killed 148 people in 1979 (Miller 1983: 15).

The eruption is unpredictable which Sinila in that period was not acknowledged as the dangerous crater rather than Timbang crater, which no far from Sinila crater, known as the poisonous crater and has history of eruption in 1928 and 1939. Thus, the eruption of Sinila crater killed more than one hundred people in Sumberrejo village. The second one is land slide which killed most of the people in a hamlet which one people leaved in this village and the rest is dead. The associated myth which connected with this disaster is about the story of Sodom and Gomorah of the prophet Luth. Named is the hamlet Lagetang, one part of the Pekasiran village, who lost only in one night when it happened in 16 April 1955. Long time before the landslide happened, Lagetang well-known with its crop that the inhabitant affluent but with those excess, the society did not be grateful with the God's gift. There doing some attitude that forbidden by the religious role as like gambling, sexual deviate and lack of the religious practice.

Every night, they organize an erotic dance and finished with the sexual orientation among them and in the night of the disaster, they do that forbidden religious activity. Thus, this disaster associated with the attitude of the Lagetang inhabitant as the punishment for them consequently. From those two stories of disaster, the Pekasiran and Sumberrejo inhabitant has a past traumatic of the disaster. The appropriated religious belief that supported their psychological bad memories of the religious 
resurgence make them join with the sect of "purist Islam" which acknowledged the cultural ritual and unoriginal religious practice as bid'ah one. So it slowly diminished practice regarding this perspective.

The distinguishing between sacred and profane is the big issues for them as the practice of Islamic purifying. However, Ekstrom (2007) said that ritual is cannot be separated from the sacred view and the sacred is also bond in profane so there is no possibility sacred without profane and conversely. Moreover, ritual is the sacramental action with the ordinary behavior, object and substance but it still retains the original and ordinaries from the realities (Ekstrom 2007: 234). There are two kinds of the religious belief which effected to the victim of the disaster, internal and external factors (Kemkens 2013: 62).

Internal factor can be seen on the concept of the suffering after the disaster where the religion plays a big role of feeling and psychological context. In this case, I agree with Kemkens's perspective which the role of religion also can embed into the disaster discourse also. Because when the disaster comes, the role of the religion here could be come as the response of the human suffering. The concept of the suffering also can be debatable where it also cannot be feel for the religious (http://daerah.sindonews.com/read/1086458/29/kisah-dusun-sodom-gomorah-di-banjarnegarayangdilaknat-tuhan-bagian-1-1455806276.

Retrieved in 15 August 2016 people. The panic situation when disaster surely with the less of his religiosity, the contradicted situation would be different faced by religious people because he would response as the God's order that should be respond calmly without his self-suffering but feels other suffering yet it level of the piety. It was happened after the disaster; it was happened in case of Pekasiran and Sumberrejo which has history of disaster indeed it added with the myth religious deviation which connected with the religious belief and practice. The external factor here can be point of the consideration of the belief in disaster ritual. The social engagement that have been done by the disaster ritual contains the meaning of sharing empathy not only physically but also psychologically.

The existence of the ritual gives a calmness for the victim in remembrance the disaster and also the ritual which packed by the festival likes give the power to forget what happen in the past. Conserving the culture is the next issues should be mentioned here cause with the different place also have different way of the rites and also the pride of the cultural ancestor that time by time slowly diminished with the more modernized society and reformed its religion without diminishing the local culture and practice.

\section{d. The Present of The Muslim Youth in Multiculturalism Society}

In the multiculturalism discourse, there were three step of the condition that happened in the society in negotiating the appropriated decision in various complexity of multiculturality. The step does not concern on the suitale indication should be taken but rather than as the providable consideration in resonance of the people respond of diverse culture. First, the "public reason" that mentioned by the John Rawl the basic standard of the human interaction among the other to find its mutuality of the understanding and tolerance in multicultural society.

In his book "the law of the people", He stated: The term "peoples," then, is meant to emphasize these singular features of peoples as distinct from states, as traditionally conceived, and to highlight their moral character and the reasonably just, or decent, nature of their regimes. It is significant that peoples' rights and dutiesin regard to their so-called sovereignty derive from the Law of Peoples itself, to which they would agree along with other peoples in suitable circumstances. As just or decent peoples, the reasons for their conduct accord with the corresponding principles (Rawls 1999: 27)

The explanation above indicate that every person has the distinction with the other, can be said multiculturalism, which differentiate from its character and morality in responding the other. Regarding those condition, the individual should obey the other people perspective as the "corresponding principle" for the public reason as the basic standard of decision. But when 
understanding the justice of the democracy, the idea of the public reason is still questionable cause it rises one sidedness of the decision.

Moreover, this idea is also still utopist, can be seen on the term "public" that has created from individuality but it does not consider the present of personal matter. It was different with Chantal Mouffe (2005) who criticized about the idea of public reason where it criticized about the conception of good is very different for every personality, hence it also potentially regulates a conflict among society. Here, Mouffe offers the theory of "agonistic pluralism" to differentiate between the agony and antagonism. deliberative democracy is can be advocated here where the consensus a basic stand of the practice (Mouffe 2013: 17).

The last is critics comes from Bikkhu Parekh in his Book "rethinking multiculturalism". The Rawls pluralism which focused on the morality diversity rather than looking for the good sense of the solution (2000: 81). But when we see about the conception of the good, every religion has claimed the idea of good. So here, the differentiation between the good and right prioritization is influential matter arguing the political way of thinking rather than metaphysical way of conception. Here, the role of the Muslim Youth in Dieng is as the capitalist of the multiculturalism society. There was no public reason of the of the existence of the annual cultural ceremony and the consensus of the people around the space.

The different interpretation of ritual that happened in the diverse society indicate how the respond of the various way of thinking in multi identity place. The different sect of Islam which picturing in the three categorizations as like traditionalist, modernist and puritanism point out in this place but the diversity was still acknowledged in this tourism attraction place. The direct response of the youth Muslim in conserving not only the cultural heritage of the Javanese but also the Islamic teaching. It can be seen from the arrangement of the agenda of Dieng Culture Festival which currently added with 'pengajian' agenda and such program in the mosque although there was no the religious agenda schedule at the first time of the annual ceremony. The presence of the youth also creates a condusive multiculturalism society in the way of the conception of good for every people.

The mutual understanding of good mark with its impact spiritually, economically and socially in relation. Spiritual affect provides from the cultural ceremony which advocate Javanese culture as the descendant of spiritual tradition. Wayang, ruwatan and tahlilan is the traditional way of religion for the Javanese conformist people who feel its religiosity from those jurisdictions. The economically influence can be seen on the tourism discourses approach which it can promote the place as the beautiful and suitable place for the spare time. The existences of the hostels, inn, the souvenir seller, the entrance payment for the hiking and other tourism seem give the positive efficacy of tourism potency. And the last is social effect of the tourism festival also tightening the relationship among the people in different area of the village.

Dieng Culture Festival is multiarea and multiage ceremony which engage not only youth people and also the matured and old people to join the agenda. The fact that Dieng Volcano range admitted into two regencies, Banjarnegara and Wonosobo, also unite this two societies into the festivity. The theory of "spectacle attraction" in the tourism place by McDaniel (2015) is suitable for this case of the multiculturalism society way of negotiation. The festival offers new ways of understanding architecture, leisure, entertainment, and religion in the region (McDaniel 2015: 3).

The other approach also mentioned by Bremer (2015) which he gives three considerations of the tourist attraction. The first is by promoting "calendar of the events" due to attract the huge tourist by showing musical, art and also the historical-architectural art which put educational mission behind those events by "calendar and guide" in promoting the tourism then after that, making 6 The religious speech from the religious people and reading the religiously text Interview with Eko, a 25 years old Youth in 29 July 2016 fellowship as the last step of this guide. So unconsciously the step of teaching 
and fellowshipping have been done to the visitors because of their experiences in the site which influence in spiritual commitment.

The next one is how the money circulation and negotiation of preservation of the site. Maintaining the tourism zone by souvenir sealing and food service around the temple becomes a particular agenda of the tourism promotion. The last is the role of the authoritarian with the ownership which also includes resistance behind it as like missionaries. Controls of the management and presentation of the tourism place effected to the consumption object that has been received by visitors managed by organized people also. But here the resistance come from the Javanese cultural conservation through promoting festival which also supported by the management.

Therefore, the economic, social, theological and political orientations that constitute the meaning ascribed to tourism place can be approach in the analysis of these places as spaces contestation that are embedded in larger national and international contexts. Considering how the discourse and practices surrounding these sites is deployed in the construction and contestation of normative definitions of religion, returning to the question of how to define the practice of travel to places of religious import in the multiculturalism society.

\section{Conclusion}

Dieng Cultural festival is annual festival which arranged by the local people since 2006 at the first time to help the kids with rambut gembel regarding its myth of bad condition for them and mystical consideration. But by the time, it is become the popular annual festival in promoting the tourism place effecting to the society economically, spiritually and socially in relation. Regarding the multiculturalism society in the Dieng Volcano range, the diffuse response of the various sect of the identity also rise while the Dieng Cultural Festival and other ritual was held.

But the response of the Youth Muslim indicates the way of the multiculturalism negotiating the situation which started from the idea of the public reason by John Rawl then how to distinguish the definition of the agony and antagonym. And the last the idea of good and right reason in multiculturalism society by Bikkhu Parekh. Showing the youth participation in Dieng Cultural Festival which seem has the positive effect to the local inhabitant point out their spirit of engagement, development and also their spirituality of belief.

Moreover, as the last consideration, I will take Parekh understanding culture which started from the nature and structure of the culture itself. Then it will rise the dynamics of the interaction that the diversity of the culture as the way of thinking. Evaluating and respecting the culture that happened in the self and other identity could be the basic standard of the political interaction in the multiculturalism society.

\section{REFERENCES}

Bremer, Suzanne, (2001). Tourism and Religion at Temple Square and Mission San Juan Capistrano. The Journal of American Folklore, Vol. 113, No. 450, Holidays, Ritual, Festival, Celebration, and Public Display (Autumn, 2000), pp. 422-435

Ekstrom, Linda, Richard D. Hecht. (2007) Ritual Performance and Ritual Practice: Teaching the Multiple form and dimensions of the Ritual in Teaching Ritual edited by Catherine Bell, New York: Oxford University Press. Pp. 225-250

Esposito, John. L, Darrel B. Fasching, Todd Lewis. (2006). World Religion Today: second edition. New York: Oxford University Press.

http://daerah.sindonews.com/read/1086458/29/kisah-dusun-sodom-gomorah-dibanjarnegara-yangdilaknat-tuhan-bagian-1-1455806276 
Kearnes, Matthew, Klauser, Francisco, Lane, Stuart. (2012) Critical Risk Research (Practices, Politics and Ethics): Religion and Disaster in Anthropological Research. US: John Wiley and Son's Publisher

Kemkens, L. (2013). On the Connection between Religion and Disaster: Literature Review, Yogyakarta: CRCS UGM.

Kreps, Gary. A. (1998) Disaster as Systemic Event and Social Catalyst in E. Quarantelli, What Is a Disaster: Perspectives on the Question London: Routledge Publisher

Lauzerie, Henry. (2016). The Making of Sufism: Islamic reform in Twentieth century. US: Columbia University Press

McDaniel, Justin Thomas. (2015). Spectacle Attractions and Buddhism in Southeast Asia. In: DORISEA Working Paper Series, No. 15.

Miller C Dar, R. Sukhyar, Santoso, S Hamidi (1983). Eruptive History of Dieng Mountain Region Central Java, and Potential Hazzard for the future eruption. United Stated Department of the Interior Geological Survey.

Mouffe, Chantal. (2005). The limits of John Rawls's pluralism", Politics Philosophy Economics. http://www.sagepublications.com

Mouffe, Chantal. (2013). What is Agonistic Politics", in Agonistics - Thinking the World Politically. UK: Verso Press

Online Resources

Parekh, Bikkhu. (2000). Rethinking Multiculturalism. London: McMillan Press Post, P. et. Al. (2003). Disaster Ritual: Exploration of an Emerging Ritual Repertoire. Leuven: Peeters.

Rawls, John. (1999). The Law of People: The Idea of Public Reason Revisited. USA: Harvard University Press

Stallings, Robert. (2005). Disaster, Crisis, Collective Stress and Mass Deprivation in Ronald, W. Perry, E.L. Quarantelli: What Is a Disaster, Xlibris Corporation 